\title{
A.C. МOСЯКIH
}

Інститут ботаніки імені М.Г. Холодного НАН України

вул. Терещенківська 2, м. Київ, 01601, Україна

amosyakin@gmail.com

\section{СУДИННІ РОСЛИНИ ФЛОРИ УКРАЇНИ, ШО Е ВИСОКОІНВАЗІЙНИМИ В ПІВНІЧНІЙ АМЕРИЦІ: ТАКСОНОМІЧНИЙ АНАЛІЗ}

Ключ о в і сло в а: інвазійні види, таксономічний аналіз, філогенія, флора, Україна, Північна Америка

\section{Ветуп}

Численні представники природної флори України є інвазійними в інших частинах світу, зокрема в Північній Америці, проте багатовимірний феномен «обміну» інвазійними рослинами між Північною Америкою та Східною Европою (Plant invasions..., 1997; Mack, Erneberg, 2002; Mack, 2003; A. Mosyakin, 2008 та ін.) залишається ще недостатньо вивченим. Значну увагу українські дослідники приділяли інвазіям американських рослин в Україні та на прилеглих територіях (Протопопова, 1973, 1991;Бурда, 1991; Протопопова та ін., 2003; Protopopova et al., 2006 та ін.), однак менше вивчали зворотний процес - інвазії українських видів у Північній Америці (А. Mosyakin, 2008 та ін.; А. Мосякін, 2012, 2013). Більшість досліджень інвазійних видів рослин проводяться в межах їхніх вторинних (антропогенних) фрагментів ареалів, натомість інформація про особливості таких видів у природних фрагментах інших ареалів обмежена. Для з'ясування чинників розвитку інвазійних процесів, географічної й екологічної приуроченості та прогнозування потенційного поширення інвазійних видів особливо важливими є їхні порівняльні дослідження як у межах первинних, так і вторинних фрагментів ареалу (Hierro et al., 2005 та ін.).

У статті наведено відомості про види судинних рослин природної флори України, що є високоінвазійними у Північній Америці, та здійснено їхній таксономічний аналіз.

\section{Матеріал та методи досліджень}

Принципи відбору видів для загального аналізу. За основу для такого відбору аборигенних видів флори судинних рослин України, інвазійних у Північній Америці, ми взяли декілька критеріїв.

Першим критерієм став офіційний статус інвазійної рослини. Тобто ми включали до списку лише

(C) A.C. MOСЯKIH, 2014 ті рослини, які офіційно визнані інвазійними на національному, федеральному та регіональному рівнях, на рівні окремих штатів США, провінцій і територій Канади (принаймні одна географічна одиниця, з певними винятками). Другим критерієм відбору видів була доведена тенденція до інвазійності або висока інвазійна активність, за офіційними даними Департаменту (міністерства) сільського господарства США (USDA - United States Department of Agriculture), відповідних установ Канади (CBCN Canadian Botanical Conservation Network) тощо.

До списку включені лише види природної флори України (аборигенні) та деякі таксони, що $є$ імовірними (сумнівними) археофітами на території нашої держави. Проте археофіти у будь-якому випадку були наявні (за визначенням) на території України до відкриття Америки Х. Колумбом. Усі доведені археофіти, всі види, що культивуються, а також релікти культури до списку видів не долучалися. Окрім того, не були включені і види з незначним інвазійним успіхом у вторинному фрагменті ареалу. До остаточного списку ввійшли 84 види судинних рослин, абсолютна більшість з яких $€$ інвазійними видами, що проникають у природні та напівприродні рослинні угруповання та значно змінюють їхню структуру (так звані environmental weeds, transformers). Під час відбору видів особлива увага також приділялася таксономічно критичним групам і видам, пріоритетним для впровадження біологічного контролю.

Таксономічна основа дослідження. Для таксономічного аналізу ми взяли за основу традиційне розуміння обсягів родин та родів, переважно за чеклістом С.Л. Мосякіна і М.М. Федорончука (Mosyakin, Fedoronchuk, 1999), але з урахуванням деяких новітніх таксономічних та номенклатурних уточнень на основі сучасних поглядів на філогенетичну систему покритонасінних. Окремо здійснено аналіз за сучасною філогенетичною схемою. Зокрема, критично враховані системи М. Чейза та 
У. Джадда та ін. (Judd et al., 1999, 2007), П. Стівенса (Stevens, 2001-onwards), В. Хейвуда та ін. (Heywood et al., 2007), Д. Мабберлі (Mabberley, 2008), Дж. Ревіла (Chase, Reveal, 2009), Дж. Ревіла (Reveal, 2011, 2012).

Загалом наше розуміння обсягів родин відповідає викладеному в узагальнюючій статті С.Л. Мосякіна (2013) «Родини і порядки квіткових рослин флори України: прагматична класифікація та положення у філогенетичній системі». Проте, на відміну від системи, прийнятої в згаданій статті, ми вважаємо за доцільне розглядати родину Scrophulariaceae у традиційному обсязі, включно 3 Veronicaceae, геміпаразитними представниками Orobanchaceae, з більшою частиною Plantaginaceae в розумінні APG (але без Plantaginaceae s. str.) тощо, хоча тепер уже доведено (зокрема на основі молекулярно-філогенетичних даних), що ця група є філогенетично штучною, а її представники мають розподілятися по кількох монофілетичних групах рангу родини. Таке рішення зумовлене необхідністю порівняння наших результатів з даними інших досліджень, де Scrophulariaceae розглядається здебільшого в традиційному обсязі. Ми також вважаємо, що недоцільно включати Chenopodiaceae до Amaranthaceae s. 1. (sensu APG), Sparganiaceae до Typhaceae s. 1., Viburnaceae - до Adoxaceae s. 1. і розглядаємо ці групи як окремі родини, згідно з недавно запропонованим варіантом системи для родин, представлених у флорі України (Мосякін, 2013). Ми поки що утримуємося від включення Najadaceae до Hydrocharitaceae.

На рівні номенклатури родів визнається самостійність роду Jacobaea Mill. (Senecio L. s. 1.), що доведено молекулярно-філогенетичними дослідженнями (Pelser et al., 2002). Ми також визнаємо відокремленість роду Pilosella Vaill. від Hieracium L.

У таксономічно спірних випадках, якщо існують альтернативні точки зору (обидві з яких є більш чи менш правомірними) на систематику та номенклатуру певного таксона, ми також враховували ті таксономічні рішення, які здебільшого прийняті в країнах Північної Америки, зокрема ті, що застосовуються в офіційній онлайновій базі даних Департаменту (міністерства) сільського господарства СШA USDA Plants (http://plants.usda.gov) (USDA, NRCS, 2010).

На рівні макросистеми покритонасінних ми відмовилися від традиційного розділення відділу Magnoliophyta на два класи, за трьома остан- німи варіантами системи А.Л. Тахтаджяна (Тахтаджян, 1987; Takhtajan, 1997, 2009): дводольні (Magnoliopsida $=$ Dicotyledonae) та однодольні (Liliopsida $=$ Monocotyledonae), оскільки тепер однозначно доведено, що дводольні у традиційному розумінні є парафілетичною групою (APG, 1998; APG II, 2003; APG III, 2009; див. обговорення у статті: С. Мосякін, 2013). Відповідно, існують пропозиції визнати в межах покритонасінних три класи (Stuessy, 2010; С. Мосякін, 2013) або ж узагалі відмовитися від виділення класів у цій групі (APG III, 2009; Chase, Reveal, 2009 та ін.). Проте для нашого аналізу це рішення не є принциповим, тим більше, що група «умовно дводольних» базальних покритонасінних - Magnoliopsida s. str. у розумінні С.Л. Мосякіна (2013), або ж Archaeangiospermae у розумінні Т. Стьюссі (Stuessy, 2010) - у нашому списку зовсім не представлена.

Далі в тексті статті автори таксонів наводяться лише для видів, оскільки авторство надвидових таксонів вказано в цитованих публікаціях (наприклад, Reveal, 2012; С. Мосякін, 2013 та ін.) та електронних базах даних.

\section{Обговорення результатів досліджень}

Загальний список видів судинних рослин природної флори України (тобто аборигенних на їі теритоpii), які є інвазійними у Північній Америці, налічує 84 види (деякі з них прийняті у широкому розумінні, включаючи дрібніші географічні раси та «мікровиди»). Всі вони належать до відділу покритонасінних (Magnoliophyta).

У нашому списку виразно домінують представники справжніх дводольних - Rosopsida (68 видів, або $81 \%$; належать до 30 родин); однодольні (Liliopsida) представлені 16 видами (19\%, належать до 8 родин). Це відповідає загальній тенденції розподілу видів між цими двома групами у більшості регіональних флор земної кулі (Вульф, 1944; Толмачев, 1970, 1986; Тахтаджян, 1978; Вальтер, 1982).

Більшість представників однодольних (9 видів) належать до філогенетично просунутої родини Poасеае; інші родини однодольних (Butomaceae, Convallariaceae (= Ruscaceae s. 1.), Iridaceae, Hydrocharitaceae, Najadaceae, Potamogetonaceae, Sparganiaceae) представлені одним видом кожна.

Таксономічний аналіз показав, що інвазійні у Північній Америці види природної флори України належать до 38 родин, серед яких за кількістю видів переважають родини Asteraceae (14 видів, 


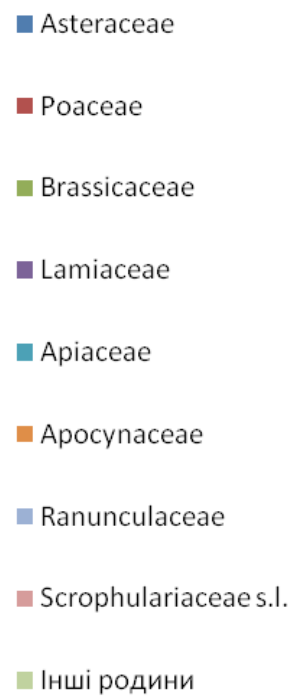

$16,7 \%)$, Poaceae $(9,10,7 \%)$, Brassicaceae $(6,7,1 \%)$, Lamiaceae (4, 4,8 \%), Apiaceae (3, 3,6 \%) та ін. (див. рисунок).

Провідна за кількістю видів родина Asteraceae представлена в нашому списку 14 видами 38 родів, а caмe: Carduus acanthoides L., C. crispus L., C. nutans L. s. 1., Centaurea diffusa Lam., C. jacea L., C. stoebe L. s. 1., Chondrilla juncea L., Jacobaea vulgaris Gaertn. (= Seneciojacobaea L.), Onopordum acanthium L., Pilosella aurantiaca (L.) F. Schultz \& Sch.Bip. (=Hieracium aurantiacum L.), P. caespitosa (Dumort.) P.D. Sell \& C. West $(=H$. caespitosum Dumort.), P. officinarum F. Schultz \& Sch. Bip. (=H. pilosella L.), Tanacetum vulgare L., Tussilago farfara $\mathrm{L}$.

Переважання представників Asteraceae цілком очікуване, оскільки ця родина містить велику кількість видів, які є адвентивними та часто інвазійними у багатьох регіонах земної кулі. За оцінками А.Л. Тахтаджяна (Takhtajan, 2009), родина налічує до 1600 родів та 23000 видів; близькі оцінки (1620 родів і приблизно 23600 видів) наводять П. Стівенс (Stevens, 2001-onwards) та Д. Мабберлі (Mabberley, 2008). Отже, ця родина є найбільшою за кількістю видів серед усіх родин дводольних. 3-поміж усіх покритонасінних за цим показником родина поступається лише родині Orchidaceae, яка містить 750-800 родів та $20000-25000$ видів, за оцінкою А.Л. Тахтаджяна (Takhtajan, 2009). Проте цілком імовірно, що оцінка кількості видів орхідних є дещо завищеною. Наприклад, П. Стівенс (Stevens, 2001-onwards) наводить для Orchidaceae такі дані: 880 родів і приблизно 22000 видів. У такому разі родина Asteraceae за кількістю видів виходить на перше місце серед усіх покритонасінних.

До другої за чисельністю видів (у нашому списку) родини Роасеае належать 9 видів із 9 родів: Aegilops cylindrica Host, Anisantha tectorum (L.) Nevsky (=Bromus tectorum L.), Cynodon dactylon (L.) Pers., Elytrigia repens (L.) Desv. ex Nevski, Glyceria maxima (C. Hartm.) Holmb., Nardus stricta L., Phalaroides arundinacea (L.) Rausch., Phragmites australis (Cav.) Trin. ex Steud. та Poa compressa L.

Родина Brassicaceae (Cruciferae, nom. altern.) представлена в нашому аналізі шістьма видами: Alliaria petiolata (M. Bieb.) Cavara \& Grande, Berteroa incana (L.) DC., Isatis tinctoria L. s. 1., Lepidium latifolium L., Rorippa amphibia (L.) Besser, R. austriaca (Crantz) Besser. 3 родини Lamiaceae (Labiatae, nom. altern.) до списку потрапили чотири види: Acinos arvensis (Schur) Dandy, Ajuga reptans L., Origanum vulgare L. s. 1., Salvia pratensis L. s. 1.

По три види кожна мають родини Apiaceae (Umbelliferae, nom. altern.; 3 видами Aegopodium podagraria L., Angelica sylvestris L., Anthriscus sylvestris (L.) Hoffmann), Apocynaceae (incl. Asclepiadaceae; види Vincetoxicum hirundinaria Medik., $V$. rossicum (Kleopow) Barbar., Vinca minor L.), Ranunculaceae (Ficaria verna Huds. = Ranunculus ficaria L., Ranunculus acris L., R. repens L.), Scrophulariaceae s.1. (incl. Plantaginaceae p.p. sensu APG, Veronicaceae etc.; види Linaria genistifolia (L.) Mill., L. vulgaris Mill., Verbascum thapsus L.).

Двома видами кожна представлені родини Aceraceae (Acer platanoides L., Acer pseudoplatanus L.), 
Euphorbiaceae (Euphorbia cyparissias L., E. esula L. s. 1.), Fabaceae (Leguminosae, nom. altern.: Sarothamnus scoparius (L.) W.D.J. Koch, Securigera varia (L.) Lassen = Coronilla varia L.), Lythraceae (Lythrum salicaria L., L. virgatum L.), Polygonaceae (Rumex acetosella L., R. crispus L.), Primulaceae s. 1. (incl. Myrsinaceae: Lysimachia nummularia L., L. vulgaris L.), Rhamnaceae (Frangula alnus Mill. = Rhamnus frangula L., Rhamnus cathartica L.), Rubiaceae (Galium odoratum (L.) Scop., G. mollugo L.), Viburnaceae s. str. (Adoxaceae s. 1.: Viburnum lantana L., V. opulus L.).

Всі інші родини представлені одним видом кожна: Berberidaceae (Berberis vulgaris L.), Boraginaceae (Echium vulgare L.), Butomaceae (Butomus umbellatus L.), Campanulaceae (Campanula rapunculoides L.), Caryophyllaceae (Gypsophila paniculata L.), Chenopodiaceae (Amaranthaceae s. 1., sensu APG: Salsola tragus L. = Kali tragus (L.) Scop.), Convallariaceae (Convallaria majalis L.), Haloragaceae (Myriophyllum spicatum L.), Hydrocharitaceae (Hydrocharis morsus-ranae L.), Hypericaceae (Hypericum perforatum L.), Iridaceae (Iris pseudacorus L.), Menyanthaceae (Nymphoides peltata (S.G. Gmel.) Kuntze), Najadaceae (Najas minor All.), Onagraceae (Epilobium hirsutum L.), Papaveraceae (Chelidonium majus L.), Peganaceae (Peganum harmala L.), Plantaginaceae s. str. (Plantago lanceolata L.), Potamogetonaceae (Potamogeton crispus L.), Sparganiaceae (Typhaceae s. 1., sensu APG: Sparganium erectum L.), Tamaricaceae (Tamarix ramosissima L.), Zygophyllaceae (Zygophyllum fabago L.). Але якщо розглядати родину Najadaceae не як самостійну, а в складі Hydrocharitaceae, як це пропонується у сучасних зведеннях (APG III, 2009; Stevens, 2001-onwards; С. Мосякін, 2013 та ін.), то тоді Hydrocharitaceae s. 1. міститиме два види (Hydrocharis morsus-ranae та Najas minor).

Серед 66 родів із нашого списку за кількістю видів переважають Carduus, Centaurea, Pilosella (по три види), далі йдуть Acer, Galium, Euphorbia, Linaria, Lisymachia, Lythrum, Ranunculus, Rumex, Viburnum, Vincetoxicum (по два види); інші ж роди представлені кожен одним видом. Якщо включати рід Frangula до складу роду Rhamnus (як це пропонується в низці сучасних зведень та онлайнових баз даних на основі молекулярно-філогенетичних відомостей), то останній рід також буде представлений двома видами, Rhamnus cathartica та $R$. frangula (= Frangula alnus).
Звертає на себе увагу той факт, що всі три провідні роди, які в нашому списку представлені трьома видами кожен, належать до родини Asteraceae. Аналіз, проведений П. Пишеком (Pyšek, 1997, 1998; Pyšek, Richardson, 2007), показав, що висока репрезентативність видів Asteraceae серед інвазійних рослин у різних регіонах світу є, очевидно, не лише наслідком просто великої кількості видів у родині, а й обумовлена цілою низкою біологічних особливостей представників родини. К. Делер (Daehler, 1998) відзначає, що найбільше видів сільськогосподарських бур'янів на глобальному рівні (порівняно з їхньою кількістю в інших родинах) також $є$ представниками родин Asteraceae та Pоaceae. Проте він припускає, що така висока репрезентативність бур'янових та інвазійних видів з цих родин $є$ просто наслідком великої кількості видів у цих групах, з чим навряд чи можна погодитися.

На основі аналізу значного масиву первинної літератури П. Пишек (Pyšek, 1997, 1998) відзначає, що найвища концентрація родин, які містять інвазійні види, спостерігається серед каріофілід (зокрема порядок Caryophyllales) та астерид: ці неформальні групи в тогочасному розумінні П. Пишека здебільшого відповідають підкласам у системах А.Л. Тахтаджяна (Тахтаджян, 1987; Takhtajan, 1997, 2009) та деяких інших авторів. Найбільші за кількістю видів родини, зокрема Asteraceae, Poaceae, Fabaceae, Brassicaceae, становлять основну частку в загальній чисельності адвентивних (чужорідних) видів у багатьох регіональних флорах світу. Якщо ж зробити поправку на різну кількість видів у різних родинах, то тоді до списку "донорів" найбільш інвазійних рослин долучаться родини Papaveraceae, Chenopodiaceae, Amaranthaceae, Polygonaceae, a poдини Brassicaceae та Роасеае збережуть свої провідні позиції за цим показником як в абсолютному, так і у відносному (відкоригованому за кількістю видів у родині) підрахунку. Вторинні фрагменти ареалів представників певних родин, як правило, за природними умовами аналогічні або подібні до первинних фрагментів ареалів. Найуспішніші родини (i загалом, i їхні окремі представники) часто мають специфічні особливості, які можна розглядати як передумови прояву інвазійності. Проте автор доходить висновку, що на рівні родин немає жодних морфологічних, фізіологічних, екологічних чи інших ознак чи властивостей, які можна було би розглядати як визначальний фактор інвазійної спроможності родини в цілому. Аналогічні висновки 
викладені і в інших публікаціях (Pyšek et al., 1995, 2008, 2013; Kueffer et al., 2013).

Д. Річардсон і П. Пишек (Richardson, Pyšek, 2006) також підтвердили, що найкраще представлені адвентивні та інвазійні види у групах Asteridae, Caryophyllidae та Commelinidae, які вони помилково назвали «класами» (закінчення назв таксонів вказує на те, що вони мали на увазі підкласи): «a disproportionally high representation of invasive aliens are concentrated within the classes Asteridae, Caryophyllidae and Commelinidae». На рівні родин ці дослідники відзначили Amaranthaceae, Brassicaceae, Convolvulaceae, Malvaceae, Poaceae, Papaveraceae та Polygonaceae, а також Fabaceae як родину, представники якої особливо успішні в інвазіях у природних екосистемах. Крім того, серед «інвазійно спроможних» родин відзначаються й ті, які значною мірою представлені водними або прибережноводними видами (Alismataceae, Hydrocharitaceae, Nymphaeaceae, Potamogetonaceae, Typhaceae) (Daehler, 1998; Richardson, Pyšek, 2006). Однак ци- товані вище автори не посилалися на конкретні філогенетичні схеми або системи покритонасінних. Тому ми здійснили спробу філогенетичної інтерпретації таксономічного складу нашого списку.

Якщо взяти за основу останню філогенетичну схему Групи 3 філогенії покритонасінних (Angiosperm Phylogeny Group) (APG III, 2009; Chase, Reveal, 2009) та прагматичну класифікаційну схему, нешодавно запропоновану С.Л. Мосякіним (2013), то можна спробувати наочно визначити, в яких саме таксономічних групах різного рангу (порядках, підкласах тощо), або ж уживаних у системі APG безрангових групах, концентруються інвазійні види нашого списку. Для цього ми склали відповідну таблицю, де співвіднесли представлені в нашому списку родини з таксонами вищого рангу, переважно порядками та підкласами. Ми також врахували і деякі безрангові групи (розиди, астериди, фабіди, мальвіди, ляміїди, кампануліди тощо), які відповідають певним визначеним кладам і неформально визнаються у системі APG.

Представленість інвазійних у Північній Америці рослин природної флори України в таксонах вищих рангів та їхнє положення у філогенетичній системі

\begin{tabular}{|c|c|c|c|c|}
\hline $\begin{array}{l}\text { Клас / підклас } \\
\text { (Мосякін, 2013) }\end{array}$ & $\begin{array}{c}\text { Порядок } \\
\text { (Мосякін, 2013) }\end{array}$ & $\begin{array}{c}\text { Порядок } \\
\text { (APG III, 2009) } \\
\end{array}$ & Родини & $\begin{array}{c}\text { Кількість інвазійних } \\
\text { видів у списку }\end{array}$ \\
\hline \multirow{2}{*}{ Liliopsida / Alismatidae } & Alismatales & Alismatales & Butomaceae, Hydrocharitaceae, Najadaceae & 3 \\
\hline & Potamogetonales & Alismatales & Potamogetonaceae & 1 \\
\hline Liliopsida / Liliidae & Asparagales & Asparagales & Iridaceae, Convallariaceae & 2 \\
\hline \multirow{2}{*}{ Liliopsida / Commelinidae } & Typhales & Poales & Sparganiaceae & 1 \\
\hline & Poales & Poales & Poaceae & 9 \\
\hline Rosopsida / Ranunculidae & Ranunculales & Ranunculales & Berberidaceae, Ranunculaceae, Papaveraceae & 5 \\
\hline Rosopsida / Hamamelidae & Saxifragales & Saxifragales & Haloragaceae & 1 \\
\hline \multirow{5}{*}{$\begin{array}{l}\text { Rosopsida / Rosidae } \\
\text { (клада Fabids) }\end{array}$} & Zygophyllales & Zygophyllales & Zygophyllaceae & 1 \\
\hline & Fabales & Fabales & Fabaceae & 2 \\
\hline & Rhamnales & Rosales & Rhamnaceae & 2 \\
\hline & Hypericales & Malpighiales & Hypericaceae & 1 \\
\hline & Euphorbiales & Malpighiales & Euphorbiaceae & 2 \\
\hline \multirow{3}{*}{$\begin{array}{l}\text { Rosopsida / Rosidae } \\
\text { (клада Malvids) }\end{array}$} & Myrtales & Myrtales & Lythraceae, Onagraceae & 3 \\
\hline & Sapindales & Sapindales & Aceraceae, Peganaceae & 3 \\
\hline & Brassicales & Brassicales & Brassicaceae & 6 \\
\hline \multirow{3}{*}{ Rosopsida / Caryophyllidae } & Polygonales & Caryophyllales & Polygonaceae & 2 \\
\hline & Tamaricales & Caryophyllales & Tamaricaceae & 1 \\
\hline & Caryophyllales & Caryophyllales & Caryophyllaceae, Chenopodiaceae & 2 \\
\hline \multirow{2}{*}{$\begin{array}{l}\text { Rosopsida / Asteridae (базальні } \\
\text { клади) }\end{array}$} & Primulales & Ericales & Primulaceae (incl. Myrsinaceae) & 2 \\
\hline & Gentianales & Gentianales & Apocynaceae, Rubiaceae & 5 \\
\hline \multirow{2}{*}{$\begin{array}{l}\text { Rosopsida / Asteridae (клада } \\
\text { Lamiids) }\end{array}$} & Boraginales & Boraginales & Boraginaceae & 1 \\
\hline & Lamiales & Lamiales & Lamiaceae, Scrophulariaceae, Plantaginaceae & 8 \\
\hline \multirow{3}{*}{$\begin{array}{l}\text { Rosopsida / Asteridae (клада } \\
\text { Campanulids) }\end{array}$} & Asterales & Asterales & Campanulaceae, Asteraceae, Menyanthaceae & 16 \\
\hline & Dipsacales & Dipsacales & Viburnaceae & 2 \\
\hline & Apiales & Apiales & Apiaceae & 3 \\
\hline ЗАГАЛОМ & & & & 84 \\
\hline
\end{tabular}


Отже, в нашому списку представлені всі три підкласи однодольних, що визнаються у прагматичній системі (С. Мосякін, 2013). Вісім родин однодольних розподілені по п'яти порядках за прагматичною системою, або трьох порядках системи APG III. Серед підкласів, цілком очікувано, за рахунок родини Poaceae (9 видів у списку) порядку Poales переважає підклас Commelinidae (10 видів), який містить найбільш еволюційно просунуті та філогенетично прогресивні родини.

Дешо несподіваною може здатися доволі широка репрезентативність підкласу Alismatidae, який серед однодольних є філогенетично базальним i до нього належать здебільшого родини, представники яких зберегли чимало примітивних рис, притаманних анцестральним Liliopsida. Ця обставина пояснюється тим, що серед алісматид широко репрезентовані водні та прибережно-водні рослини, які досить схильні до інвазій, переважно за рахунок значної азональності водного середовища та його подібності на різних континентах.

Дводольні в нашому списку представлені всіма п'ятьма підкласами класу справжніх дводольних (Rosopsida), визнаними у прагматичній системі (Мосякін C., 2013). Проте їхнє представництво є нерівномірним. Базальних покритонасінних (клас Magnoliopsida у вузькому розумінні) у списку немає взагалі.

Підклас Ranunculidae та порядок Ranunculales представлені трьома родинами, серед яких найбільше видів у нашому списку (3) має родина Ranunculaceae, найбільша в межах порядку за кількістю видів (понад 2500 у світовій флорі).

Невеликий за кількістю видів підклас Hamamelidae у нашому списку репрезентований лише одним видом родини Haloragaceae, до якої належать здебільшого водні рослини.

Підклас Rosidae представлений 10 родинами 3 двох субклад (фабід і мальвід). До першої з них у нашому списку належать 8 видів із п'яти родин п'ятьох порядків (чотирьох порядків за системою APG III). По два види в нашому списку містять родини Euphorbiaceae, Rhamnaceae та Fabaceae. Субклада мальвід представлена набагато краще: до неї належать 9 видів з п'яти родин трьох порядків. Очікуваним є переважання Brassicaceae (6 видів), по два види мають Aceraceae та Lythraceae. Отже, загалом підклас Rosidae представлений у нашому списку 17 видами.

У підкласі Caryophyllidae до родин зі значною репрезентативністю інвазійних видів нале- жать Polygonaceae, Tamaricaceae, Caryophyllaceae, Chenopodiaceae. Вони представлені в нашому списку п'ятьма видами загалом; цей підклас за обсягом приблизно відповідає порядку Caryophyllales у системі APG III.

Серед справжніх дводольних (клас Rosopsida, безрангова група Eudicots у системі APG III) у нашому списку очікувано переважають представники філогенетично найбільш просунутого підкласу Asteridae, причому за кількістю як родин (12), так і видів (37). До базальних клад підкласу (порядки Primulales, Gentianales) належать 7 видів. Клада ляміїд (безрангова група Lamiids у системі APG) представлена 9 видами з 4 родин та 2 порядків; очевидним є переважання родин Lamiaceae та Scrophulariaceae/Plantaginaceae (філогенетично просунуті ляміїди). Найбільш представлена в нашому списку клада кампанулід (безрангова група Campanulids у системі APG III): 21 вид з п'яти родин і трьох порядків. Asteraceae, Apiaceae та Campanulaceae є родинами, в яких інвазійні види репрезентовані доволі широко (особливо це стосується першої родини).

\section{Висновки}

Високий інвазійний потенціал у Північній Америці мають 84 види (з 38 родин та 66 родів) судинних рослин природної флори України, які визнані як інвазійні на національних (США та Канада) та регіональних (штатів, провінцій і територій) рівнях. Список видів проаналізовано з погляду їхнього таксономічного та філогенетичного положення. За кількістю видів переважають родини Asteraceae, Poaceae, Brassicaceae, Lamiaceae, Apiaceae. Серед родів переважають Carduus, Centaurea, Pilosella (по 3 види), Acer, Galium, Euphorbia, Linaria, Lisymachia, Lythrum, Ranunculus, Rumex, Viburnum, Vincetoxicum (по 2 види). Більшість видів належать до підкласів Asteridae (37 видів з 12 родин) та Rosidae (17 видів 3 10 родин).

Навіть така порівняно невелика вибірка видів наочно демонструє певну кореляцію між філогенетичним положенням групи та представленістю в ній інвазійних і потенційно інвазійних видів. Отримані нами дані підтверджують гіпотезу про переважання інвазійних та потенційно інвазійних видів серед представників багатовидових, морфологічно різноманітних і філогенетично просунутих родин та родів. 
Чітке розуміння таксономічного підгрунтя інвазійних чи потенційно інвазійних рослин необхідне для передбачення та контролю інвазій. Проте, незважаючи на сучасні активні дослідження інвазій, ще залишається багато невирішених таксономічних та номенклатурних питань, що стосуються інвазійних у Північній Америці видів рослин, які походять з України, Східної Европи та прилеглих територій. Часто таксономічні та номенклатурні проблеми відбивають складність внутрішньовидових і міжвидових процесів диференціації у первинних фрагментах ареалів інвазійних видів (A. Mosyakin, 2009). Детальніше ці проблемні питання систематики розглянутих нами інвазійних видів будуть викладені в окремій статті.

Під час відборі видів для дослідження ми консультувалися з провідними фахівиями зі США, зокрема Дж. Картесом (J. Kartesz) i T. Стольгреном (Th. Stohlgren), а також із фахівцем з біоконтролю з CABI-Europe Switzerland A. Гассманом (A. Gassmann), яким висловлюємо щиру подяку. Ми також вдячні канд. біол. наук I.А. Коротченко (Інститут ботаніки імені М.Г. Холодного НАН України) за слушні поради в процесі підготовки статті до друку.

\section{СПИСОК ЛІТЕРАТУРИ}

Бурда Р.И. Антропогенная трансформация флоры. Киев: Наук. думка, 1991. - 168 с.

Вальтер Г. Общая геоботаника / Пер. с нем. и предисл. А.Г. Еленевского. - М.: Мир, 1982. - 264 с.

Вульф Е.В. Историческая география растений. История флор Земного шара. - М.; Л.: Изд-во АН СССР, 1944. $-548 \mathrm{c}$.

Мосякін А.С. Моделювання потенційного поширення Nymphoides peltata (S.G. Gmel.) Kuntze у Північній Америці // Рослинний світ у Червоній книзі України: впровадження Глобальної стратегії збереження рослин: Мат-ли II Міжнар. конф. (9-12 жовтня 2012 р., м, Умань, Черкаська обл.). - К.: Паливода А.В., 2012. - C. 141-143.

Мосякін А.С. Визначення потенційного поширення деяких видів флори України, інвазійних у Північній Америці, на основі аналізу комплексу кліматичних факторів // Біол. системи (Чернівці). - 2013. - 5, № 1. - С 80-92.

Мосякін С.Л. Родини і порядки квіткових рослин флори України: прагматична класифікація та положення у філогенетичній системі // Укр. ботан. журн. - 2013. 70, № 3. - С. 289-307.

Протопопова В.В. Адвентивні рослини Лісостепу і Степу України. - К.: Наук. думка, 1973. - 192 с.

Протопопова В.В. Синантропная флора Украины и пути ее развития. - Киев: Наук. думка, 1991. - 204 с.

Протопопова В.В., Мосякін С.Л., Шевера М.В. Вплив адвентивних видів рослин на фітобіоту України // Оцінка і напрямки зменшення загроз біорізноманіттю України
/ Відпов. ред. О.В. Дудкін. - К.: Вид-во «Хімджест», 2003. - С. 129-155.

Тахтаджян А.Л. Флористические области Земли. - Л.: Наука, 1978. - 247 с.

Тахтаджсян А.Л. Система магнолиофитов. - Л.: Наука, 1987. - $439 \mathrm{c}$.

Толмачев А.И. О некоторых количественных соотношениях во флорах Земного шара // Вестн. ЛГУ. - 1970. - № 15. - С. 62-74.

Толмачев А.И. Методы сравнительной флористики и проблемы флорогенеза. - Новосибирск: Наука, 1986. - $196 \mathrm{c}$.

Angiosperm Phylogeny Group (APG). An ordinal classification for the families of flowering plants // Ann. Missouri Bot. Gard. - 1998. - 85. - P. 531-553.

Angiosperm Phylogeny Group II (APG II). An update of the Angiosperm Phylogeny Group classification for the orders and families of flowering plants: APG II // Bot. J. Linnaean Soc. - 2003. - 141. - P. 399-436.

Angiosperm Phylogeny Group III (APG III). An update of the Angiosperm Phylogeny Group classification for the orders and families of flowering plants: APG III // Bot. J. Linnean Soc. - 2009. - 161. - P. 105-121.

Chase M.W, Reveal J.L. A phylogenetic classification of the land plants to accompany APG III // Bot. J. Linnean Soc. - 2009. - 161. - P. 122-127.

Daehler C.C. The taxonomic distribution of invasive angiosperm plants: ecological insights and comparison to agricultural weeds // Biol. Conserv. - 1998. - 84. - P. 167-180.

Heywood V.H., Brummitt R.K., Culham A., Seberg O. (eds.). Flowering plant families of the world. - Royal Botanic Gardens, Kew, 2007. - 424 p.

Hierro J.L., Maron J.L., Callaway R.M. A biogeographical approach to plant invasions: the importance of studying exotics in their introduced and native range // J. Ecology. - 2005. - 93. - P. 5-15.

Judd W.S., Campbell C.S., Kellog E.A., Stevens P.F. Plant systematics: a phylogenetic approach. - Sunderland, Mass.: Sinauer Associates, Inc., 1999. - xvi + 464 p.

Judd W.S., Campbell C.S., Kellog E.A., Stevens P.F., Donoghue M.J. Plant systematics: a phylogenetic approach. $3^{\text {rd }}$ ed. - Sunderland, Mass.: Sinauer Associates, Inc., 2007. $-565 \mathrm{p}$.

Kueffer C., Pyšek P., Richardson D.M. Integrative invasion science: model systems, multi-site studies, focused meta-analysis, and invasion syndromes // New Phytologist. - 2013. - 200. - P. 615-633.

Mabberley D.J. Mabberley's plant-book. A portable dictionary of plants, their classifications, and uses. $3^{\text {rd }}$ ed. - London: Cambridge Univ. Press, 2008. - 1040 p.

Mack R.M. Plant naturalizations and invasions in the Eastern United States: 1634-1860 // Ann. Missouri Bot. Gard. - 2003. - 90(1). - P. 77-90.

Mack R.M., Erneberg M. The United States naturalized flora: largely the product of deliberate introductions // Ann. Missouri Bot. Gard. - 2002. - 89(2). - P. 176-189.

Mosyakin A.S. Invasive plants in North America: a view from Ukraine // Biodiversity: Research and Conservation (Poznań, Poland). - 2008. - 9-10. - P. 11-18.

Mosyakin A.S. A new invasiveness hypothesis based on taxonomic and microevolutionary patterns of vascular plants // 
International Conference «Biodiversity. Ecology. Adaptation. Evolution» (Odessa, 16-19 September 2009). - Odessa: Pechatniy Dom Publ., 2009. - P. 208.

Mosyakin S.L., Fedoronchuk M.M. Vascular plants of Ukraine: A nomenclatural checklist. - Kiev, 1999. - xxiv + 346 p.

Pelser P.B., Gravendeel B., van der Meijden R. Tackling speciose genera: species composition and phylogenetic position of $\mathrm{Se}$ necio sect. Jacobaea (Asteraceae) based on plastid and nrDNA sequences // Amer. J. Bot. - 2002. - 89(6). - P. 929-939.

Plant invasions: studies from North America and Europe / J.H. Brock, M. Wade, P. Pyšek, D. Green (eds.). - Leiden: Backhuys Publ., 1997. - 223 p.

Protopopova V.V., Shevera M.V., Mosyakin S.L. Deliberate and unintentional introduction of invasive weeds: A case study of the alien flora of Ukraine // Euphytica. - 2006. - 148. - P. 17-33.

Pyšek P. Compositae as invaders - better than the others? // Preslia (Praha). - 1997. - 69. - P. 9-22.

Pyšek $P$. Is there a taxonomic pattern to plant invasions? // Oikos (Copenhagen). - 1998. - 82. - P. 282-294.

Pyšek P., Hulme P.E., Meyerson L.A., Smith G.F., Boatwright J.S., Crouch N.R., Figueiredo E., Foxcroft L.C., Jarošík V., Richardson D.M., Suda J., Wilson J.R. Hitting the right target: taxonomic challenges of, and for, biological invasions // AoB Plants. - 2013. - 5: plt042 (Electronic journal).

Pyšek P., Prach K., Šmilauer P. Invasion success related to plant traits: an analysis of Czech alien flora // Plant invasions General aspects and special problems / P. Pyšek, K. Prach, M. Rejmánek \& M. Wade (eds.). - Amsterdam: SPB Academic Publ., 1995. - P. 39-60.

Pyšek P., Richardson D.M. Traits associated with invasiveness in alien plants: Where do we stand? // W. Nentwig (ed.). Biological invasions, Ecological Studies 193. - Springer-Verlag, Berlin \& Heidelberg, 2007. - P. 97-126.

Pyšek P., Richardson D.M., Pergl J., Jarošík V., Sixtová Z., Weber E. Geographical and taxonomic biases in invasion ecology // Trends in Ecology and Evolution. - 2008. - 23(5). - P. 237-244.

Reveal J.L. Summary of recent systems of angiosperm classification // Kew Bulletin. - 2011. - 66. - P. 5-48.

Reveal J.L. An outline of a classification scheme for extant flowering plants // Phytoneuron. - 2012. - 2012-37. - P. 1-221.

Richardson D.M., Pyšek P. Plant invasions: Merging the concepts of species invasiveness and community invasibility // Progress in Physical Geography. - 2006. - 30. - P. 409-431.

Stevens P.F. (2001-onwards) Angiosperm phylogeny website. Version 12, June 2008-onwards. http://www.mobot.org/ MOBOT/research/APweb/ (Last accessed May 2014).

Stuessy T.F. Paraphyly and the origin and classification of angiosperms // Taxon. - 2010. - 59. - P. 689-693.

Takhtajan A.L. Diversity and classification of flowering plants. - New York: Columbia Univ. Press, 1997. - 663 p.

Takhtajan A. Flowering plants. - Berlin: Springer Verlag (Springer Science+Business Media B.V.), 2009. - xlvi + $872 \mathrm{p}$.

USDA, NRCS. 2014. The PLANTS Database (http://plants. usda.gov, accessed 2014). National Plant Data Center, Baton Rouge, LA 70874-4490 USA.

Рекомендує до друку

Надійшла 30.12.2014 p.
А.С. Мосякин

Институт ботаники имени Н.Г. Холодного НАН Украины, г. Киев

\section{СОСУДИСТЫЕ РАСТЕНИЯ ФЛОРЫ УКРАИНЫ, ВЫСОКОИНВАЗИВНЫЕ В СЕВЕРНОЙ АМЕРИКЕ: ТАКСОНОМИЧЕСКИЙ АНАЛИЗ}

Высокий инвазивный потенциал в Северной Америке имеют 84 вида сосудистых растений природной флоры Украины, которые признаны инвазивными на национальных и региональных (штаты, провинции и территории) уровнях. Список видов проанализирован с точки зрения их таксономического и филогенетического положения. Эти виды относятся к 38 семействам и 66 родам. По количеству видов преобладают семейства Asteraceae (14 видов, 16,7 \%), Poaceae (9 / 10,7 \%), Brassicaceae (6 / 7,1 \%), Lamiaceae (4 / 4,8 \%), Apiaceae (3 / 3,6 \%). Среди родов преобладают Carduus, Centaurea, Pilosella (по 3 вида), Acer, Galium, Euphorbia, Linaria, Lisymachia, Lythrum, Ranunculus, Rumex, Viburnum, Vincetoxicum (по 2 вида). Большинство видов относятся к подклассам Asteridae (37 видов из 12 семейств) и Rosidae (17 видов из 10 семейств). Результаты таксономического анализа подтверждают гипотезу о преобладании инвазионных видов среди представителей многовидовых, морфологически разнообразных и филогенетически продвинутых семейств и родов.

Ключ в в е сло в а: инвазивные виды, таксономический анализ, филогения, флора, Украина, Северная Америка.

\section{A.S. Mosyakin}

M.G. Kholodny Institute of Botany, National Academy of Sciences of Ukraine, Kyiv

\section{VASCULAR PLANTS OF THE FLORA OF UKRAINE HIGHLY INVASIVE IN NORTH AMERICA: A TAXONOMIC ANALYSIS}

High invasive potential in North America is peculiar to 84 species of vascular plants native to Ukraine, which are recognized as invasive at national and regional (states, provinces and territories) levels. The list of taxa has been analyzed from the viewpoints of their taxonomic position and modern phylogenetic placement. These species belong to 38 families and 66 genera. By the number of species, the following families prevail: Asteraceae (14 species, $16.7 \%)$, Poaceae (9 / $10.7 \%)$, Brassicaceae (6 / $7.1 \%)$, Lamiaceae $(4 / 4.8 \%)$, Apiaceae $(3 / 3.6 \%)$. Best represented are the genera Carduus, Centaurea, Pilosella (3 species each), Acer, Galium, Euphorbia, Linaria, Lisymachia, Lythrum, Ranunculus, Rumex, Viburnum, Vincetoxicum (2 species each). Most species belong to the subclasses Asteridae ( 37 species of 12 families) and Rosidae (17 species of 10 families). These and other results of taxonomic analysis support the hypothesis on the prevalence of invasive species among species-rich, morphologically diverse and phylogenetically advanced families and genera.

Ke y word s: invasive species, taxonomic analysis, phylogeny, flora, Ukraine, North America. 